\title{
Analysis of Land Use Change and Forestation in Response to Demographic Movement and Reduction of Forest Crime
}

\author{
Mahmut Muhammet Bayramoğlu ${ }^{1 *}$, Ali İhsan Kadıoğulları ${ }^{1}$ \\ ${ }^{1}$ Faculty of Forestry, Karadeniz Technical University, Trabzon, TURKEY
}

Received 7 May 2017 - Revised 15 September 2017 • Accepted 5 October 2017

\begin{abstract}
The sustainable management of natural resources requires a thorough analysis of the land-use and forest cover dynamics and the effective factors in the changes occurring in them. This study investigated the roles played by social factors in the temporal changes in land cover and deforestation within the Torul State Forest Enterprise in northeastern Turkey. Between 2005 and 2016, this area was examined in terms of forest crime, demographic movement and forest dynamics using the Geographic Information System (GIS). Major changes were observed in the temporal dynamics of the forested areas and their parameters, with an overall net increase of $3.26 \%$. There was a productive forest area increase of 16.459 ha. Regenerated-young stand areas had increased because of the regeneration activities carried out over the period. This was partially due to decreased forest crime, decreased rural population and increased gross national product (GNP), which had been below Turkey's average.
\end{abstract}

Keywords: forestation, GIS, demographic movement, forest crime, educational precautions

\section{INTRODUCTION}

Over the last 30 years, the number of studies focusing on the human-environment relationship has been increasing in order to determine the socio-demographic structure and the effect of the changes on forest assets (Call et al., 2017). In this context, the impact of the population on natural resources as the most important element of the sociodemographic structure is the main topic of the continuing work on the population-environment relationship (Tritsch \& Le Tourneau, 2016). Especially in the study of tropical forests, the impact of population density on deforestation in the region has been revealed (Lopez-Carr \& Burgdorfer, 2013; Laurance et al., 2014). Many investigations have found the human attitude to be the most fundamental factor in changing the patterns of land use on a local, regional and global scale (Wyman \& Stein, 2010). According to Newman et al. (2014), the factors that influence the increase and decrease of forest existence on the global scale fall into five groups which vary from region to region and include economic (urbanization, modernization, industrialization, relative poverty), political, technological, cultural and demographic factors. Sloan (2007) demonstrated the dynamics of these sociodemographic factors to be the occupational status, the population density, and the age composition of the people of the region. The process of converting forests into agricultural and pasture lands results in an increase in employment in the region as well as in a sudden rise in income. However, in the following years this leads to a serious reduction in forest resources and a decrease in soil fertility (Sears et al., 2007). This negativity brings limited socio-economic benefits as well as high environmental costs (Weinhold et al., 2015). However, after a long period of time, the negative impact on the forest is transformed into a dynamic form that increases the presence of forests (Angelsen, 2007). Due to this transformation, positive effects can be seen including increased protection of forests, the importation of wood products due to lower costs, and an increase in the income of the rural population (Lambin \& Meyfroidt, 2010). Moreover, according to the environmental Kuznets curve hypothesis, the environmental pollution that increases with industrialization will decrease after a certain point. This is especially the case for people living in the rural areas, for as their incomes increase, they will benefit from the ecological and socio-cultural functions of the forests rather than from the raw materials of the wood. For this reason, a balance of protection and utilization of the forest areas can be achieved by eliminating or reducing the pressure on them. 


\section{Contribution of this paper to the literature}

- Land use change in the region has been revealed.

- The change in the forests was examined up to the diameter steps and the structural change of the forest was determined.

- Structural change of forests has been associated with demographic and socio-economic change.

In addition to the socio-demographic impacts on forest areas, land-use/land-cover changes have been investigated for a long time and many studies have been conducted to analyze the factors effecting this change. In these studies, land-use/land-cover change (Sancar et al,. 2009; Özen Turan et al., 2010; Şen et al., 2015), forest dynamics (Başkent \& Kadığulları, 2007; Kadığulları \& Başkent, 2008; Günlü et al., 2009; Kadığulları, 2013; Padilla et al., 2010; Kadığulları et al., 2014), forest succession (Terzioğlu et al., 2009; Terzioğlu et al., 2010), spatial changes of land-cover types (Özen Turan et al., 2010; Paudel \& Yuan, 2012; Meneses et al., 2017), population growth (Bewket, 2002), pasturing (Calvas et al., 2013), urbanization (Dewan et al., 2012; Alphan \& Nil, 2016; Alphan, 2017) and global market forces (Beilin et al., 2014) have all been examined by researchers. In these studies, many references such as satellite images and forest-management plan maps have been used. Forest-management plans were completed for the first time in Turkey between 1963 and 1972 and these provided the basis of forest land/cover changes. From the beginning of that planning period to the present, forest management plans have been updated periodically every 10 or 20 years. When comparing the management-plan inventory data from the first planning period (19631972) with those of 2015, a net increase of 2.143.639 ha in total forest area can be seen. During this period (43 years), the amount of productive forest area increased by 3.847.691 ha, while degraded forest areas decreased by about 1.704.052 ha (GDF, 2015).

This study analyzed the effects of forest crime change and demographic movement on the spatio-temporal changes in forest-cover type and stand parameters in a typical mountain forest ecosystem of Turkey over a specific time period. The objectives of this research were to: (1) map land-use/land-cover change over an 11-year period; (2) map forestation and transition of stand parameters by using GIS; (3) describe the ways in which demographic movement and forest-crime changes affect forestation/deforestation.

\section{MATERIALS AND METHODS}

\section{Study Area}

Torul State Forest Enterprise is located in a typical mountain watershed covering an area of 150.434,2 ha in northeastern Turkey, according to the boundaries of the 2016 stand-type maps (Figure 1). The altitude varies between 500 and $3.200 \mathrm{~m}$ above sea level with an average slope of approximately $24 \%$ (Kadığuları et al. 2008). The Torul State Forest Enterprise officially encompasses the town of Torul. Between 2000 and 2015, the demographic characteristics of Torul were mostly dominated by the diminishing rural population due to migration to urban centers, both within and outside of the district (Table 1) (Anonymous 2016b.). During the study period, the urban population of Torul District grew by $14 \%$ (from 8.080 to 11.313), whereas the rural population decreased by nearly half (from 22.882 to 12.701). Thus, although there was an increase in the total urban population, in the Torul Forest Enterprise, the total rural population had decreased from 30.962 to 24.014 (Table 1) (Anonymous 2016b).

An examination of the socioeconomic structure of the area revealed that the gross national product (GNP) of the Torul District was below the national average, with most of the population making a living from agriculture and and livestock breeding. However, it is obvious that the rate of national income per capita had increased regularly from 2004 to 2015, in proportion with the average of Turkey. The income of people living in the rural area and in the central city increased and consequently, their approach to the environment changed as the threshold of the Kuznets curve was reached (Table 2) (Anonymous 2016a.). In addition to the GNP values, the change in the amount of forest crime was also examined. There was a steady decline in the forest crimes commited in the Torul Forest Enterprise after the relative increase during the 2007-2008 general election period, and ratio of the Torul forest crime rate versus the total amount of forest crime in Turkey showed a steadily declining change (Table 3) (Anonymous 2015). 
EURASIA J Math Sci and Tech Ed

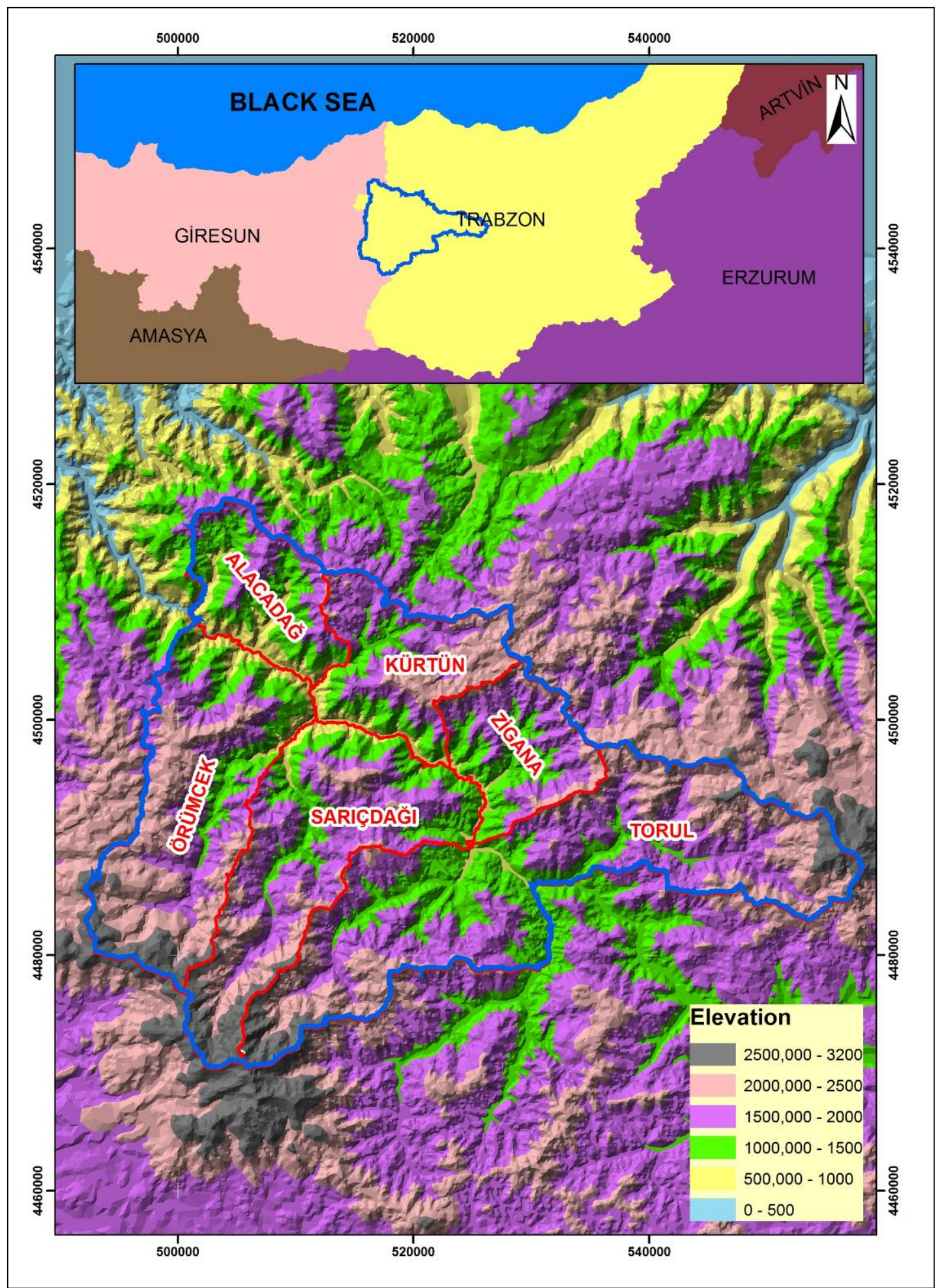

Figure 1. The geographic location of the study area surrounded with solid blue lines and foret planning units with red lines 
Bayramoğlu \& Kadıoğulları / Land Use Change and Social Factors

Table 1. Demographic Change in The Torul Forest Enterprise

\begin{tabular}{ccccc}
\hline \multirow{2}{*}{ Year } & \multicolumn{4}{c}{ Torul State Forest Enterprise } \\
\cline { 2 - 5 } & Urban & Rural & Total & \% (based on initial value) \\
\hline 2000 & 8.080 & 22.882 & 30.962 & 100.0 \\
\hline 2007 & 8.724 & 16.788 & 25.512 & 82.40 \\
\hline 2008 & 7.842 & 18.689 & 26.531 & 86.39 \\
\hline 2009 & 7.414 & 17.975 & 25.389 & 82.09 \\
\hline 2010 & 7.389 & 17.501 & 24.890 & 80.12 \\
\hline 2011 & 7.342 & 17.056 & 24.398 & 78.15 \\
\hline 2012 & 7.623 & 17.083 & 24.706 & 79.41 \\
\hline 2013 & 8.829 & 16.882 & 25.711 & 83.48 \\
\hline 2014 & 9.555 & 14.169 & 23.724 & 75.75 \\
\hline 2015 & 11.313 & 12.701 & 24.014 & 76.97 \\
\hline
\end{tabular}

Table 2. Change of Per Person Gross National Product in Turkey and The Torul Forest Enterprise

\begin{tabular}{cccccc}
\hline \multirow{2}{*}{ Year } & \multicolumn{2}{c}{ Turkey } & \multicolumn{2}{c}{ Torul } & \multirow{2}{*}{ \% (Torul/ Turkey) } \\
\cline { 2 - 5 } & TL & Dollar & TL & Dollar & 68.2 \\
\hline 2004 & 8536 & 5961 & 5824 & 4067 & 66.1 \\
\hline 2005 & 9844 & 7304 & 6503 & 4825 & 65.2 \\
\hline 2006 & 11389 & 7906 & 7428 & 5156 & 66.2 \\
\hline 2007 & 12550 & 9656 & 8307 & 6392 & 66.1 \\
\hline 2008 & 14001 & 10931 & 9254 & 7225 & 68.2 \\
\hline 2009 & 13870 & 8980 & 9537 & 6125 & 71.8 \\
\hline 2010 & 15860 & 10560 & 11384 & 7580 & 73.2 \\
\hline 2011 & 18788 & 11250 & 13808 & 8235 & 72.2 \\
\hline 2012 & 20880 & 11588 & 15065 & 8361 & 80.8 \\
\hline 2013 & 23766 & 12480 & 16822 & 8834 & 87.8 \\
\hline 2014 & 22732 & 10395 & 18356 & 8394 & 8127 \\
\hline 2015 & 25130 & 9261 & 22052 & & \\
\hline
\end{tabular}

Table 3. Change of forest crimes in Turkey and Torul Forest Enterprise

\begin{tabular}{cccc}
\hline \multirow{2}{*}{ Year } & Turkey & Forest Crime & \% (Torul/ Turkey) \\
\cline { 2 - 4 } & 37284 & 294 & 0.79 \\
\hline 1998 & 30162 & 323 & 1.07 \\
\hline 1999 & 29980 & 243 & 0.81 \\
\hline 2000 & 29665 & 335 & 1.13 \\
\hline 2001 & 27730 & 216 & 0.78 \\
\hline 2002 & 26814 & 218 & 0.81 \\
\hline 2004 & 22538 & 91 & 0.40 \\
\hline 2005 & 21946 & 134 & 0.61 \\
\hline 2006 & 16725 & 69 & 0.41 \\
\hline 2007 & 16700 & 134 & 0.80 \\
\hline 2008 & 14295 & 154 & 1.08 \\
\hline 2009 & 13723 & 86 & 0.63 \\
\hline 2010 & 14813 & 73 & 0.49 \\
\hline 2011 & 11528 & 55 & 0.48 \\
\hline 2012 & 12031 & 47 & 0.39 \\
\hline 2013 & 10918 & 56 & 0.51 \\
\hline 2014 & 10749 & 48 & 0.45 \\
\hline 2015 & 8813 & 37 & 0.42 \\
\hline
\end{tabular}

\section{Data Collection}

For the spatio-temporal analysis of the forest structure, first, digitization and rectification of the 2005 stand-type maps were performed (GDF, 2005), and then generation of the spatial database via Arc/Info GIS $10^{*}$ was carried out with the help of GIS specialists. Second, the digital 2016 stand-type maps were obtained from the forestmanagement plans (GDF, 2016) after which analyses of the spatial and temporal changes and the transition of land- 
Table 4. The transition matrix of land use change in Torul State Forest Enterprise from 2005 to 20016

\begin{tabular}{ccccccc}
\hline $\begin{array}{c}2005 \\
\text { Types }\end{array}$ & \multicolumn{7}{c}{ 2016 Land-Use Types } \\
\cline { 2 - 7 } & Degraded forest & Settlement & Open Areas & Productive Forest & Water & Total \\
\hline Degraded forest & 17726.3 & 14.0 & 5969.0 & 15096.8 & 125.2 & 38931.4 \\
\hline Settlement & 44.8 & 283.7 & 429.9 & 24.5 & 25.5 & 808.5 \\
\hline Open spaces & 7991.2 & 856.5 & 60072.7 & 3505.0 & 145.7 & 72571.1 \\
\hline Productive Forest & 1618.5 & 10.0 & 538.2 & 35798.5 & 0.1 & 37965.3 \\
\hline Water & 1.0 & & 4.8 & 0.2 & 151.9 & 157.9 \\
\hline Totals & 27381.8 & 1164.2 & 67014.6 & 54425.0 & 448.5 & 150434.2 \\
\hline
\end{tabular}

use types were carried out via GIS. Finally, the analysis process was completed by calculating the forest improvement or deforestation rate over the time period.

The data used in this research included the stand maps from 2005 coordinated with 1/25.000-scale topographical maps drawn in the digital environment, i.e., the maps were made from photographs and later digitized in GIS. The 2005 stand maps used 1/16.000-scale, colored, infra-red aerial photographs taken in 2002, while the 2016 stand maps used data taken in 2013 at $45 \mathrm{~cm}$ spatial resolution.

\section{Digitizing and Geometric Correction of Stand-type Maps}

The 2005 stand-type maps were scanned and coordinated using 1/25.000-scale topographical maps, and then drawn in the digital environment using UTM projection (WGS 84 data) and first-order nearest-neighbor rules, i.e., first of all, the maps were made from photographs and then these maps were digitized in GIS. The topographical maps were used for coordinate registration. The rectified forest stand-type maps were digitized with a screen view scale of $1 / 3.000-1 / 5.000$ by a group of GIS experts in the Trabzon Regional Directory of Forestry (GDF 2016).

\section{Transition and Spatial Analysis of Land-cover Types and Forest Parameters}

After the changes in the percentage of land use and forest parameters were analyzed, an evaluation of the temporal transitions among the land use types was carried out and recorded. This allowed the composition and configuration of the forest resources to be examined in relation to the temporal dynamics of various parameters. The periodic results gathered from the management plans were used to evaluate the transitions. The polygon themes for 2005 and 2016 including the land use, developmental stage and crown closure were superimposed, and then an area from each of the classes was converted to one of the other classes and computed.

\section{Analysis of Forestation / Deforestation Rate}

In addition to analyzing transitions of land-use types and forest parameters, the forest improvement or deforestation rate over time was determined for the selected period. The average forest improvement rate was computed via the compound-interest-rate method according to its explicit biological meaning (Puyravaud, 2003):

$$
P=\frac{100}{t_{2}-t_{1}} \ln \frac{A_{2}}{A_{1}}
$$

where $P$ is the percentage of productive/total forest improvement per year, and $A_{1}$ and $A_{2}$ are the amounts of total forest cover or productive forest areas at times $t_{1}$ and $t_{2}$, respectively (Kadı̆gullar1, 2013).

\section{RESULTS}

\section{Temporal Changes in Forest Structure}

A net increase of 4910 ha of total forest area occurred in the period from 2005 to 2016, as seen in the digitized stand-type maps from the forest-management plans. This led to an increase of 16.549 ha in the productive forest areas and a decrease of 11.549 ha in the degraded forest areas (Figure 2). Consequently, the net increase in the total forested areas between 2005 and 2016 was 3.26\% (Table 4, Figure 2), and the cumulative improvement of the forested area was $6.4 \%$ over the same period. 


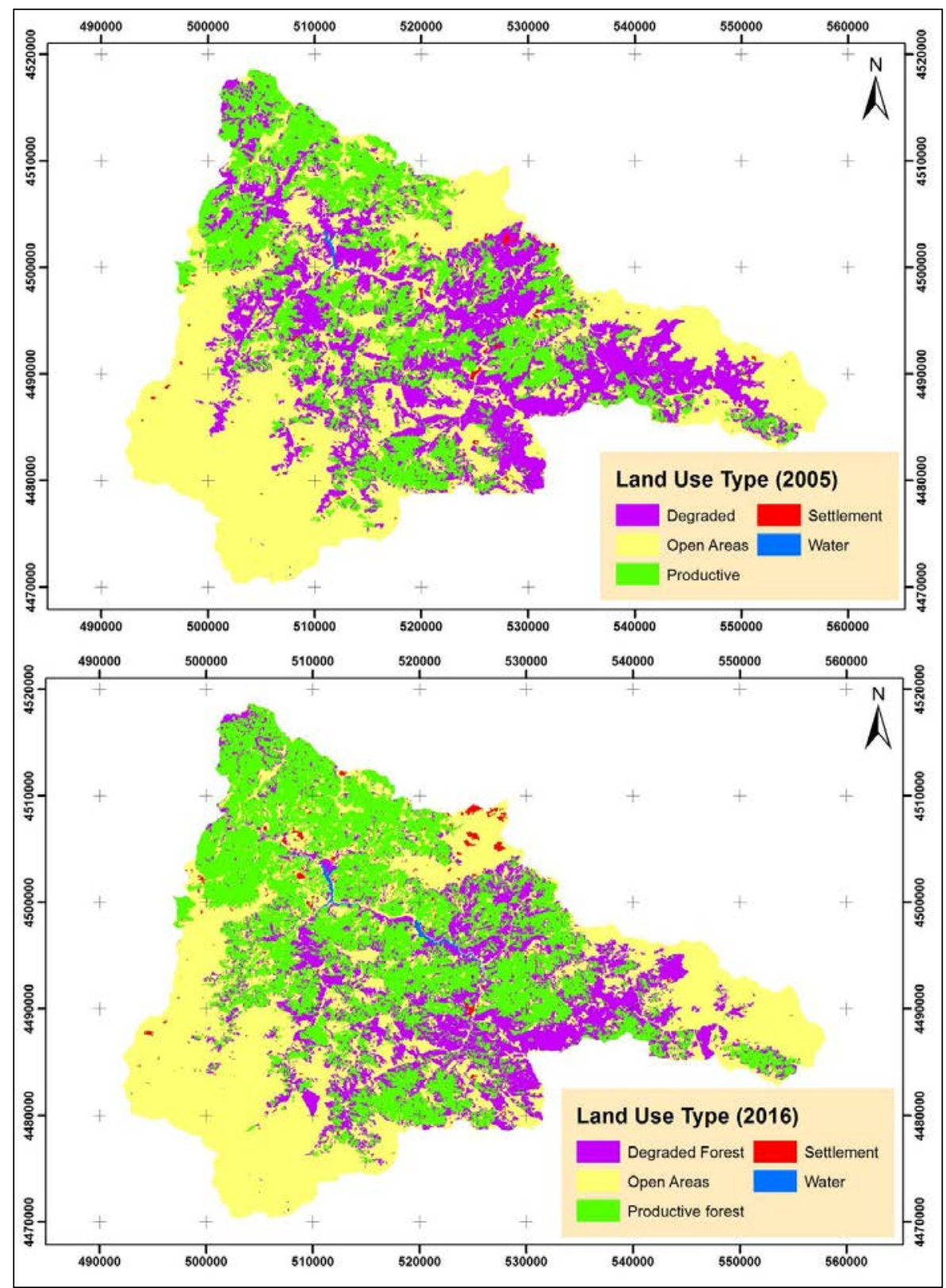

Figure 2. The spatial distribution of land use types of Torul State Forest Industry over two periods; 2005 and 2016

Further analyses of the digital stand-type maps were conducted in order to detect any structural changes in the forest by examining various parameters such as crown closure. Between the years 2005 and 2016, crown closure had increased in the total forest area, with stands classified as crown closure-3 (> 70\%) increased by around 13.3\%, crown closure- 1 stands ( $11 \%-40 \%)$ by around $2.93 \%$, and crown closure- 2 stands $(41 \%-70 \%)$ by about $6.88 \%$. Crown closure of degraded forest areas $(<10 \%)$ had decreased by about $15.01 \%$ of the landscape (Table 5, Figure 3). In general, the changes of crown closure indicated that, all crown closure areas (classes 1, 2 and 3) had increased between 2005 and 2016, while the degraded forest areas had decreased. The total forest area increase of about $6.38 \%$ (76.896,7 ha in 2005) demonstrated that the structural quality of the forest had been improved. 
Table 5. The transition matrix of crown closure classes in the study area from 2005 to 2016

\begin{tabular}{|c|c|c|c|c|c|c|c|c|}
\hline \multirow[b]{2}{*}{2005 Crown Closure Classes } & \multicolumn{8}{|c|}{2016 Crown Closure Classes } \\
\hline & $\begin{array}{c}1 \text { (low } \\
\text { coverage) }\end{array}$ & $\begin{array}{l}2 \text { (medium } \\
\text { coverage) }\end{array}$ & $\begin{array}{c}3 \text { (full } \\
\text { coverage) }\end{array}$ & $\begin{array}{c}\text { Degraded } \\
\text { forest }\end{array}$ & Settlement & $\begin{array}{c}\text { Open } \\
\text { spaces }\end{array}$ & Water & Totals \\
\hline 0 (Regenerated areas) & 45.2 & 9.6 & 60.6 & 0.1 & & 0.2 & & 115.7 \\
\hline 1 (low coverage, $11 \%-40 \%)$ & 1392.9 & 1761.7 & 1624.4 & 498.8 & 0.2 & 101.6 & 0.1 & 5379.6 \\
\hline 2 (medium coverage, $41 \%-70 \%$ ) & 1022.7 & 4253.4 & 5426.3 & 492.8 & 1.1 & 147.8 & & 11344.1 \\
\hline 3 (full coverage, $>71 \%$ ) & 649.2 & 3328.9 & 15050.4 & 605.8 & 8.7 & 277.2 & & 19920.3 \\
\hline $\begin{array}{l}\text { Degraded forest (sparsely } \\
\text { distributed, } 0-10 \%)\end{array}$ & 3495.7 & 6048.3 & 5552.8 & 17726.3 & 14.0 & 5969.0 & 125.2 & 38931.4 \\
\hline Settlement & 8.4 & 9.0 & 7.1 & 44.8 & 283.7 & 429.9 & 25.5 & 808.5 \\
\hline Open spaces & 1010.5 & 1124.9 & 1369.5 & 7991.2 & 856.5 & 60072.7 & 145.7 & 72571.1 \\
\hline Uneven aged forest & 8.5 & 101.8 & 1062.9 & 21.0 & & 11.4 & & 1205.6 \\
\hline Water & & 0.1 & 0.0 & 1.0 & & 4.8 & 151.9 & 157.9 \\
\hline Totals & 7633.1 & 16637.8 & 30154.2 & 27381.8 & 1164.2 & 67014.6 & 448.5 & 150434.2 \\
\hline
\end{tabular}

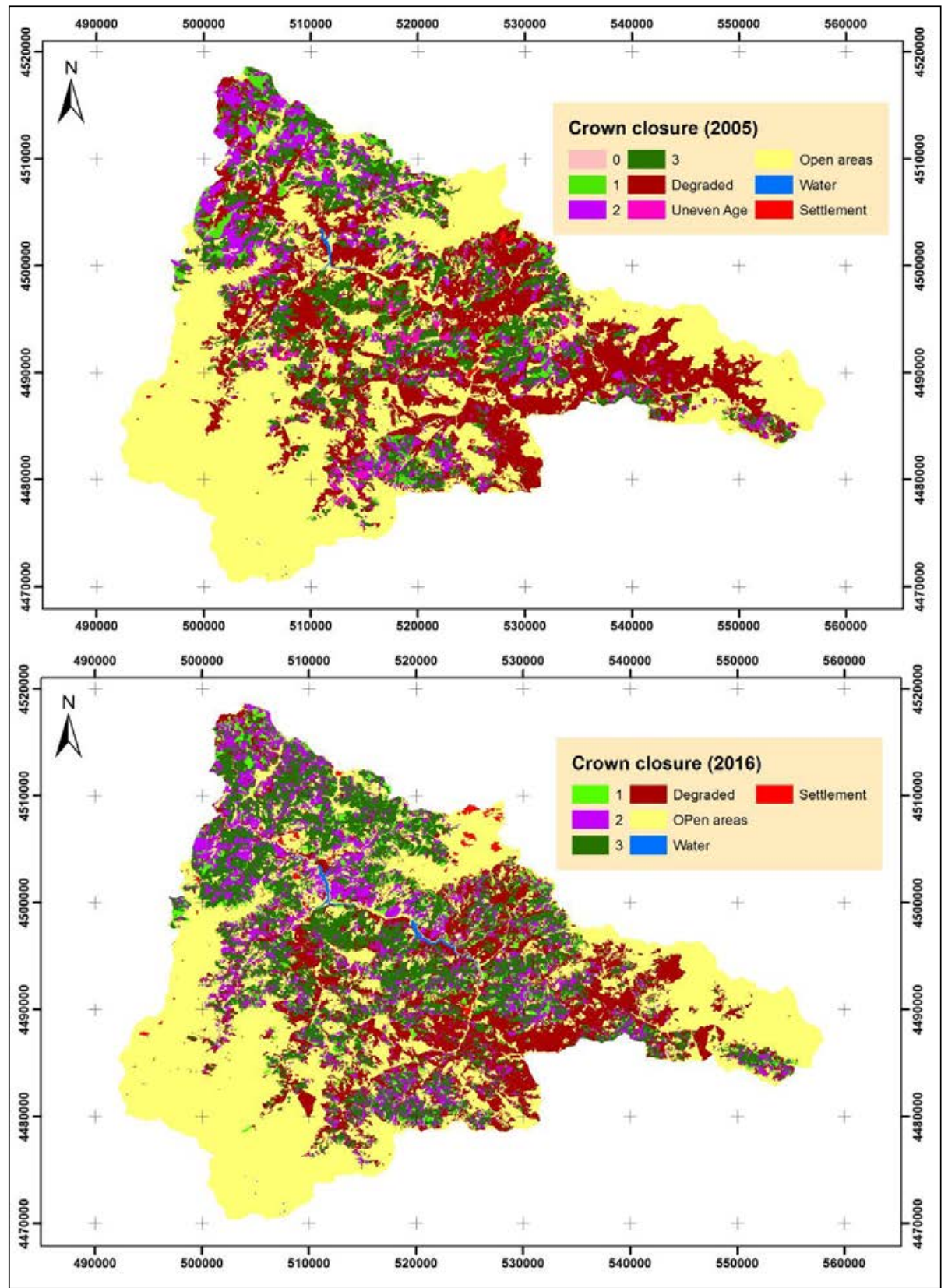

Figure 3. The spatial distribution of crown closure of Torul State Forest Industry over two periods; 2005 and 2016 


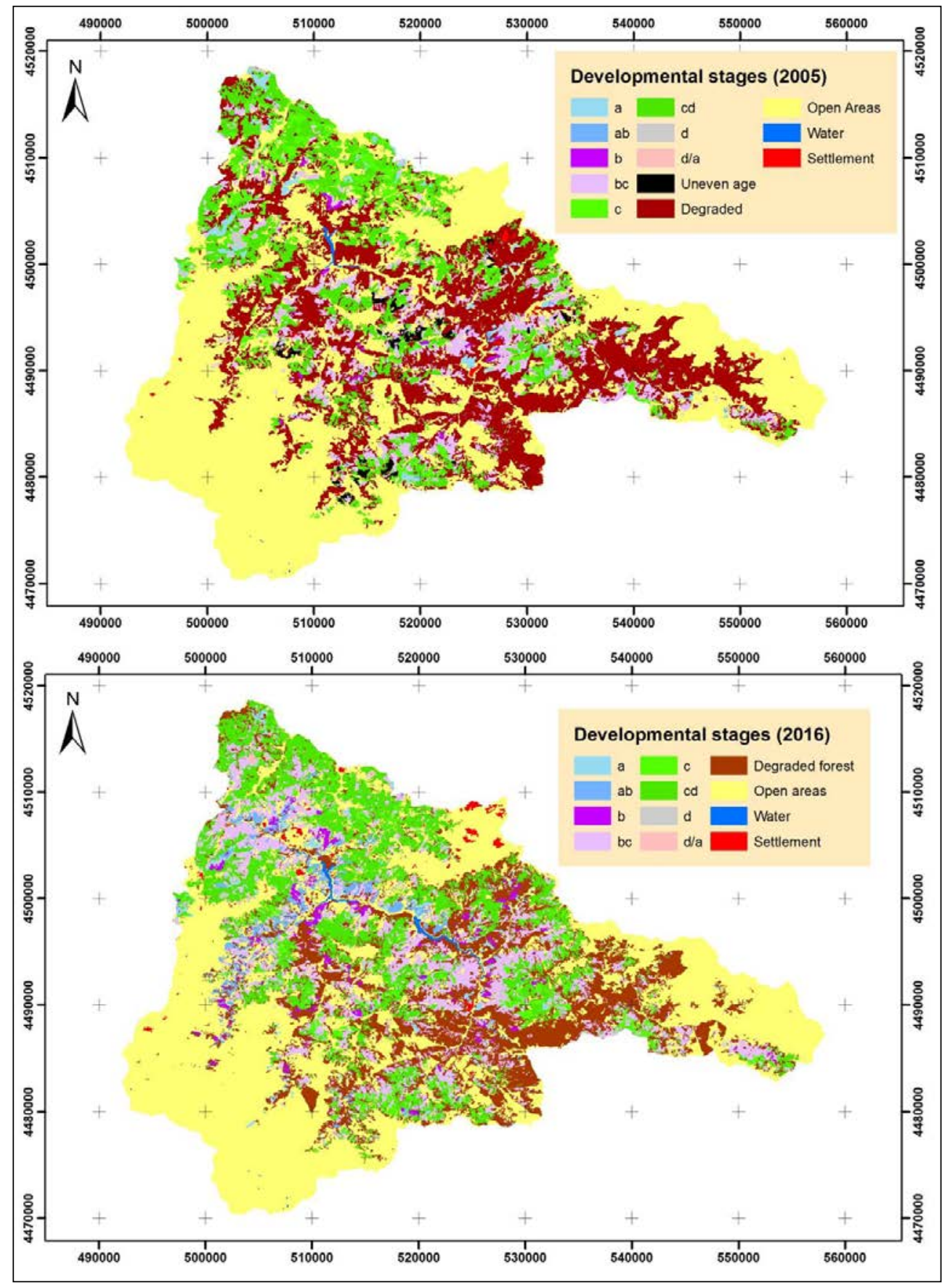

Figure 4. The spatial distribution of cover types of Torul State Forest Industry over two periods; 2005 and 2016

The parameter of the developmental stages of forest ecosystems can also be analyzed to demonstrate change in the structural quality of the forest. In the digital, 2005 stand-type maps, the forest was generally divided into developmental stage-a (regenerated), stage-bc (young/mature), stage-c (mature), stage-cd (mature/over-mature) and stage-d (over-mature), having areas of $1.727 \mathrm{ha}, 9.984 \mathrm{ha}, 7.133 \mathrm{ha}, 16.108 \mathrm{ha}$ and $1.188 \mathrm{ha}$, respectively (Table 6, Figure 4). In 2016, the forest was mostly concentrated within the developmental stages ab, bc and cd. The increases in the stages of $\mathrm{a}$ and $\mathrm{ab}$ indicated the adequacy of the regenerated areas for maintaining sustainable forestry. The remaining areas were allowed to mature into older developmental stages, with an increase in the cd stage of around 7.490 ha. 
Table 6. The transition matrix of developmental stages in the study area from 2005 to 2016

\begin{tabular}{|c|c|c|c|c|c|c|c|c|c|c|c|c|c|}
\hline \multirow{2}{*}{$\begin{array}{c}2005 \\
\text { Developmental } \\
\text { Stages } \\
\end{array}$} & \multicolumn{13}{|c|}{2016 Developmental Stages } \\
\hline & a & $\mathbf{a b}$ & b & bc & c & cd & d & d/a & Degraded & Settlement & $\begin{array}{l}\text { Open } \\
\text { areas }\end{array}$ & water & Total \\
\hline $\begin{array}{c}\text { a (regenerated, }<8 \\
\mathrm{~cm})\end{array}$ & 518.8 & 144.5 & 255.6 & 300.6 & 20.1 & 111.3 & 20.8 & 87.5 & 198.7 & 4.6 & 60.1 & & 1722.7 \\
\hline $\begin{array}{c}\mathrm{ab} \text { ( regenerated - } \\
\text { young) }\end{array}$ & 3.0 & & 20.7 & 71.8 & 1.0 & & & & 8.2 & & 3.1 & 0.1 & 108.0 \\
\hline $\begin{array}{c}\text { b (young, } 8-19.9 \\
\mathrm{~cm})\end{array}$ & 2.4 & 2.3 & 219.0 & 214.0 & 12.5 & 11.5 & & & 19.7 & & 7.7 & & 489.0 \\
\hline bc (young-mature) & 18.1 & 75.0 & 230.9 & 5581.2 & 1377.9 & 1974.1 & 36.6 & 1.3 & 575.0 & 2.1 & 112.2 & & 9984.5 \\
\hline $\begin{array}{c}\mathrm{c}(\text { mature, } 20-35.9 \\
\mathrm{cm})\end{array}$ & 23.6 & 61.7 & 21.7 & 1810.9 & 1341.8 & 3328.6 & 176.2 & 7.8 & 225.7 & 0.8 & 134.4 & & 7133.4 \\
\hline $\begin{array}{l}\text { cd (mature and } \\
\text { overmature) }\end{array}$ & 68.7 & 45.1 & 53.9 & 1889.4 & 744.0 & 11667.8 & 819.9 & 87.6 & 536.5 & 2.4 & 193.3 & & 16108.5 \\
\hline $\begin{array}{c}\mathrm{d} \text { (overmature, }>36 \\
\mathrm{~cm} \text { ) }\end{array}$ & 46.4 & 0.3 & 3.1 & 58.6 & 16.7 & 863.1 & 119.2 & 34.3 & 31.4 & & 14.9 & & 1188.1 \\
\hline $\begin{array}{l}\mathrm{d} / \mathrm{a}(\text { Overmature - } \\
\text { regenerated) }\end{array}$ & 3.5 & & 8.2 & 9.6 & 0.7 & 0.1 & & & 2.3 & & 1.2 & & 25.6 \\
\hline Degraded & 871.2 & 2452.2 & 1115.8 & 5725.8 & 846.6 & 3873.0 & 159.4 & 52.8 & 17726.3 & 14.0 & 5969.0 & 125.2 & 38931.4 \\
\hline Settlement & 2.9 & & 0.3 & 9.6 & 0.7 & 10.6 & 0.4 & 0.0 & 44.8 & 283.7 & 429.9 & 25.5 & 808.5 \\
\hline Open areas & 357.1 & 426.5 & 143.4 & 1167.5 & 185.7 & 1144.9 & 48.4 & 31.4 & 7991.2 & 856.5 & 60072.7 & 145.7 & 72571.1 \\
\hline Uneven Age & 0.6 & 0.0 & 2.2 & 365.3 & 179.7 & 613.7 & 11.6 & & 21.0 & & 11.4 & & 1205.6 \\
\hline Water & & 0.1 & & 0.0 & & & & & 1.0 & & 4.8 & 151.9 & 157.9 \\
\hline Total & 1916.5 & 3207.8 & 2074.9 & 17204.4 & 4727.4 & 23598.7 & 1392.5 & 302.8 & 27381.8 & 1164.2 & 67014.6 & 448.5 & 150434.2 \\
\hline
\end{tabular}

\section{Transition among Land Cover / Land-use Types}

Between 2005 and 2016, determination of the changes among major forest-cover types was based on digital, forest-management plan stand-type maps. A comprehensive analysis showed a transition of around 6.656 ha of total forest areas (both productive and degraded) into non-forest areas, and 11.566 ha of non-forest areas into forest areas, with a 4.910 ha net increase in forest areas. Degraded forest areas had been changed into around 15.096 ha of productive forest, whereas productive forest areas had been changed into about 1.618 ha of degraded forest. Degraded forest and open areas had been changed into about 270 ha of water areas (new dam construction). The areas that remained unchanged between 2005 and 2016 included 60.072 ha of open areas, 17.726 ha of degraded forest, 35.798 ha of productive forest and 151 ha of water (older dams constructed pre-planning) (Table 4).

The 2005 - 2016 developmental stage transitions were also analyzed via digital stand-type maps. Areas of mature, stage-c (approximately 3.328 ha) development had grown naturally into over-mature, stage-c, while 871 ha of degraded forest areas had transitioned into stage-a, as a possible result of regeneration or rehabilitation. Around 2.452 ha of degraded forests had been converted to young, stage-ab, and another 5.725 ha to stage-bc (Table 5).

Based on digital stand-type maps, subsequent analyses were carried out on the crown closure temporal dynamics and changes. Nearly 1.022 ha of fully covered areas had been heavily thinned into low coverage and 3.328 ha into medium coverage, while 1.624 ha of low-cover areas and 1.761 ha of medium-cover areas had been developed into fully covered areas. Moreover, 6.048 ha of degraded forest had been changed into medium-cover areas and 5.552 ha into fully covered areas (Table 6).

\section{Analysis of Forestation / Deforestation Rate}

In addition to the analyses of land-use type, crown closure and developmental stage transitions, the forest improvement or deforestation rate over time was established for the selected period (2005 - 2016). This was calculated as an average annual improvement rate of $0.56 \%$ for the degraded and productive forests combined, but as an average annual improvement rate of $3.27 \%$ for the productive forest areas alone. All these changes showed that the forests in general, productive forests and forest quality had all increased substantially.

\section{DISCUSSION AND CONCLUSIONS}

Turkey is a country rich in natural resources and biodiversity, with local populations living in or around the forests. In recent years, much research has been devoted to examining the population shift away from the rural areas and the related changes in land use/cover, and to analyzing the resulting forest dynamics. However, very few studies have investigated the forest dynamics associated with forest crime and the economic status of the rural population. This study employed GIS to analyze the impact of the rural population, forest crime and income status on forest dynamics and land-cover change. At the same time, the crown closure, developmental stages, land-cover 
change and the transitions between them in the Torul Forest Enterprise in particular have been presented in detail in tabular and map form.

Earlier research carried out in the same study area reported the overall changes from 1984 to 2005 using forestmanagement plans. A 19.9\% net increase in total forested areas, amounting to an annual forest improvement rate of $0.92 \%$, was found (Kadıogulları et al. 2008). Further analyses were conducted on the stand-type maps in order to detect any changes in the forest structure. In general, from 1984 to 2005, crown closure changes included decreases in class- 2 and class -1 crown closure areas, increases in class- 3 crown closure areas, increases in degraded forest and increases in the quality of the forest structure. The developmental stages of forest ecosystems can be considered as another parameter in the analysis of the changes in the quality of the forest structure. Transitions in the developmental stages in the form of changes to higher stages indicate the adequacy of regenerated areas for supporting sustainable forestry. The remainder of the area was allowed to grow into the older developmental stages, with the general interpretation that the forest had already been developing into older stages (Kadığulları et al. 2008).

Several important Turkish studies have reported similar findings. Research conducted by Kadioğulları and Başkent (2008) in the same region of northeastern Turkey found a 1.6\% cumulative forest improvement (6.928 ha) with a $6.54 \%$ rate for the forested areas for the entire Gümüşhane Province between 1987 and 2000. This amounts to an annual forest improvement rate of of $0.50 \%$, according to the Landsat images used. By examining stand-type maps of the same area, another study noted a decrease (from $50.92 \%$ in 1984 to $48.62 \%$ in 2007) in the amount of forest cover in the Rize Forest Enterprise. Between 1984 and 2007, 2.30\% of the entire area of Rize Forest Enterprise (2.299 ha) and $4.52 \%$ of the forested area had witnessed cumulative forest disturbance, amounting to a forest improvement rate of $0.20 \%$ per year. In addition, one study of the Yalnızçam and Uğurlu forest planning units in northeastern Turkey reported an average rate of $0.40 \%$ per year (1972-2005) for forest improvement (Kadığulları, 2013).

For the present study, new forest-management plan maps and the new boundaries of the study area were used. The results, in parallel with the previous studies, showed the annual rate of forest improvement from 2005 to 2016 as $0.56 \%$, based on the forest-management plans. The percentage of forest cover in Torul Forest Enterprise was shown to have increase from approximately $51.12 \%$ in 2005 to $54.38 \%$ (4910 ha) in 2016, based on the forestmanagement plans.

Moreover, similar forest improvement results have been determined for the entire country of Turkey (78.004.644 ha). Based on the first assessment of the 1963 - 1972 inventory results, Turkey had 20.199.296 ha of forest area covering about $26.1 \%$ of the country's total land area. Now, the latest forest inventory data show that, based on the forest-management plans up to the end of 2015, Turkey has 22.342 .935 ha of forest area, accounting for about $28.64 \%$ of the country's total land area, with $99.9 \%$ of the forest area owned by the state (GDF, 2015). The results indicated that the total forest areas had increased by 2.14 million ha over the 43-year period. In other words, the forested areas of Turkey exhibited increases of about 3.84 million ha of total productive forest improvement versus decreases of about 1.70 million ha of degraded forests. This translates into an average annual total forest improvement rate of $0.229 \%$, with an average annual productive forest improvement rate of $0.82 \%$. These observed trends generally have been explained by the plantation of degraded forestlands and open areas, natural regeneration on lands abandoned as a result of migration from villages inside or near forests, increased public awareness and respect for the environment and lastly, sustainable management of the forests by the General Directorate of Forestry (GDF, 2015). Considering the annual rate of total forest improvement alone, the value in the study area $(0.56 \%)$ is higher than that of Turkey as a whole $(0.17 \%)$.

Furthermore, overall crown closure changes showed that, between 2005 and 2016, productive forest areas had increased respectively by about 16.549 ha, fully covered forest areas by about 10.233 ha, and low coverage forest areas by about $5.293 \mathrm{ha}$, while the degraded forest areas had decreased by about 11.549 ha. Productive forest areas and fully covered areas had increased substantially with respect to crown closure. Another stand parameter, which of the developmental stages between 2005 and 2016, was also analyzed. Overall changes showed that stage-a and stage-ab areas had increased by about 3.290 ha, those of stage-c had decreased by about 2.406 ha, and those of stage-cd mature forest (in 2015) had increased by about 7.490 ha. These changes revealed that regenerated, young and over-mature forest areas had increased quite remarkably, whereas mature forest areas had significantly decreased.

The positive changes in both amount and quality in forest areas was also examined along with changes in the socio-economic structure. It was clear that the amount of crime in the Torul Forestry Enterprise had decreased significantly due to the population decline in the rural areas, with the changes occurring in parallel with each other (Figure 5). This course of positive change in quality and quantity was also seen in the forest ecosystem. 


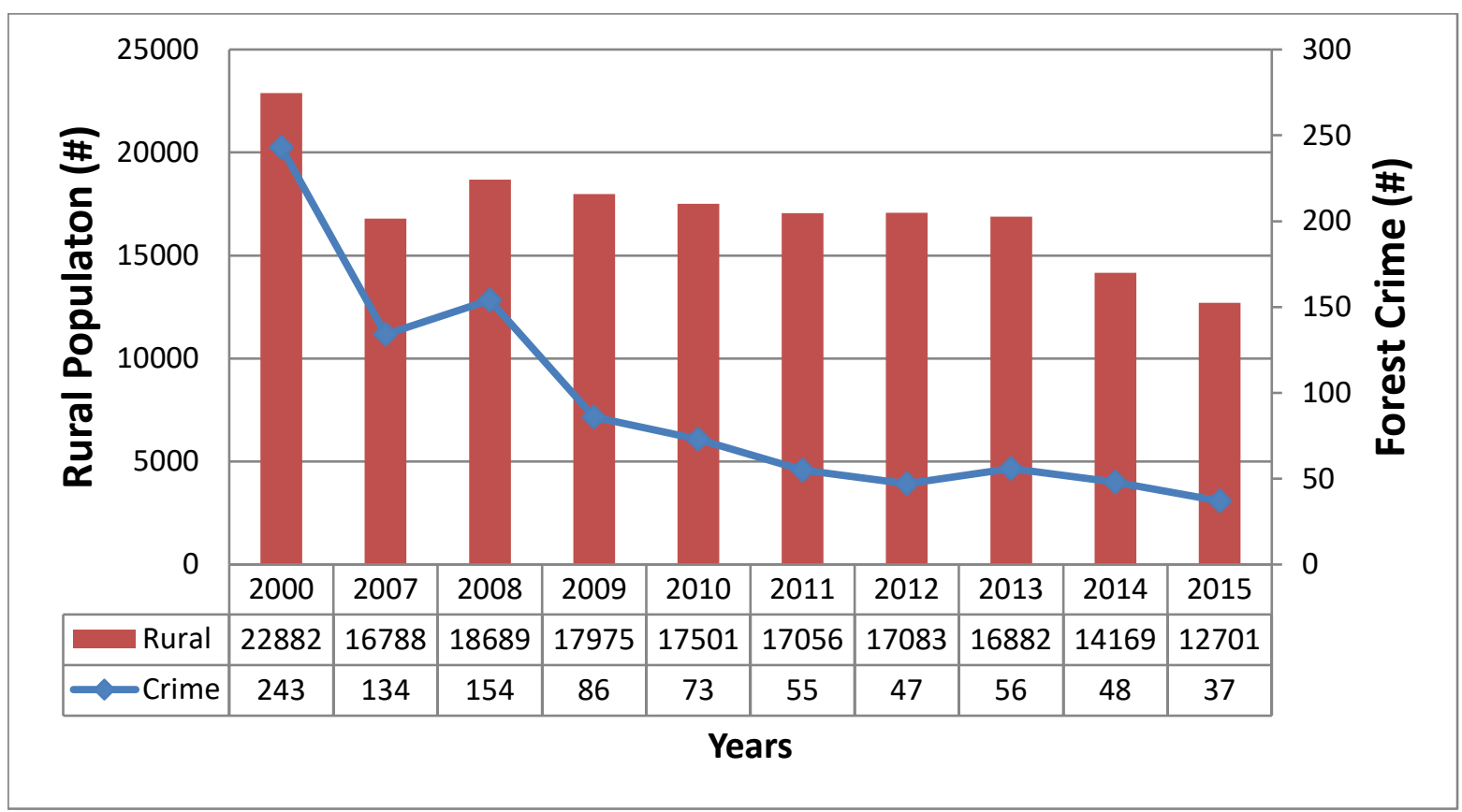

Figure 5. Change of Forest Crime and Rural population (2000-2015 year)

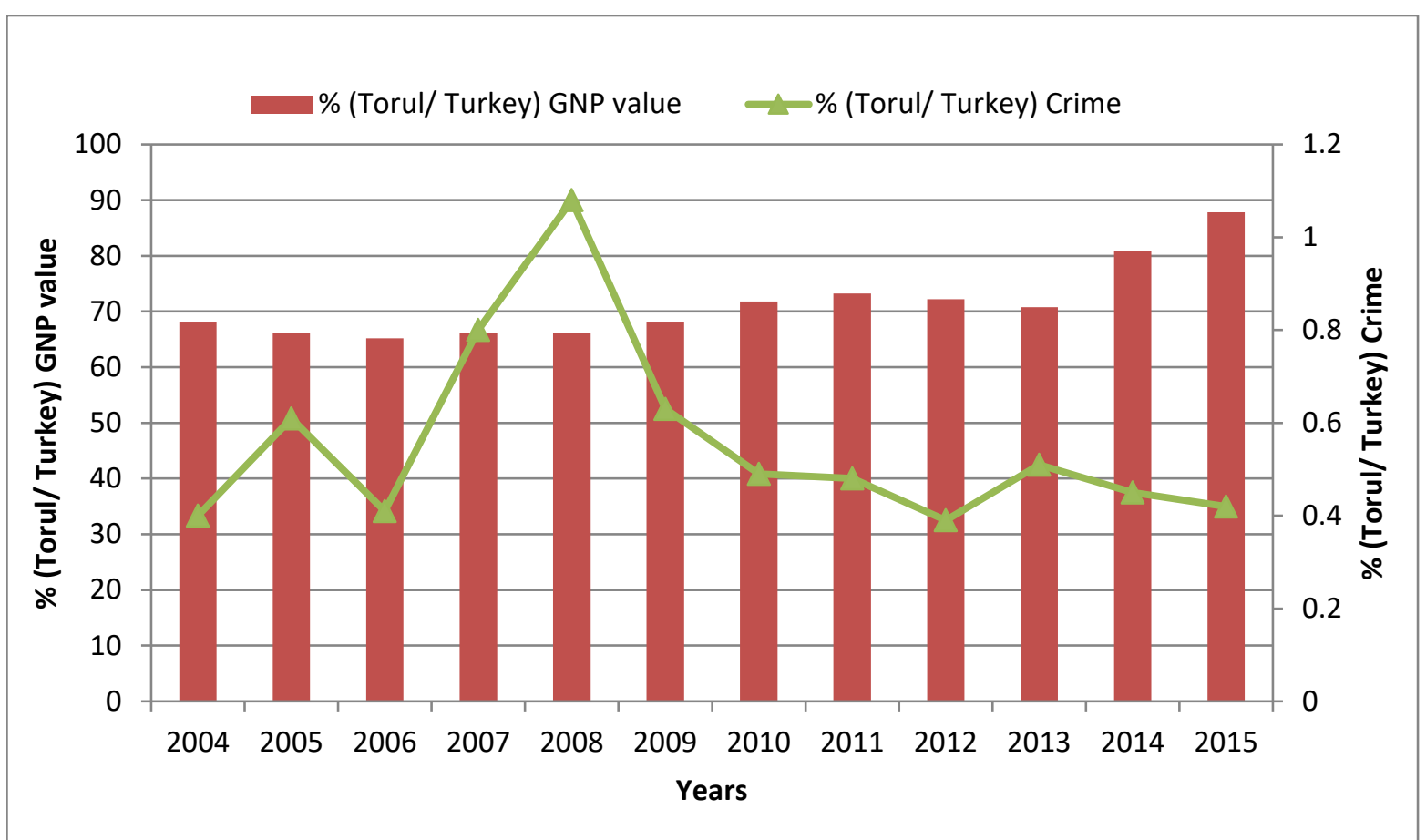

Figure 6. Change of Change of Per Person Gross National Product and Forest Crime Range of Turkey Value (2004-2015 year)

In addition, the ratio of the average national per capita income vs. that in the Torul Forest Enterprise and the average forest crime rate of Turkey as a whole vs. the local rate were analyzed. As a result of this analysis, there was an inverse relationship seen between the per capita income and the forest crime, except during the 2007-2008 general election period. This change, when explained by the Kuznet hypothesis, shows that decreases in rural population and increases in income levels lead to awareness and sensitivity to the environment over time, and to a decline in activities such as trenching and other improper utilization of forest areas. 


\section{Forestry Developments and Forestry Education}

In 19th century industrial revolution had important impact on living standards and population in Europe with market economy and developing technologies. These developments increased the demand on natural resources and forests. In order to meet with these increasing demands natural resources must be used efficiently. This situation imposes many tasks on the forest engineers who responsible for the management of the forests. Forest engineering is a profession open to nature and does not show a static structure. Many variables (social, economic, politic etc.) are influential in the profession. Therefore, another issue that such studies should reveal and which should be emphasized is the social aspect of forestry. It is known that the ecological reasons for the change in forests as well as the socio-economic characteristics of the people living in these areas are also influential. For this reason, the social dimension of forestry should be taken into account in forestry education in particular. Forestry studies in Turkey require a continuous two-way communication with people living in rural areas. The ability to live without this problem depends on the social skills of the forest engineers who work in the region (the ability to communicate, to build empathy, etc.).In this context, the necessity of socio-economic content courses that play an important role in forestry education also emerges. While the share of lessons with socio-economic content in forestry training of universities in USA, Australia and Sweden ranges between 23-36\%, in Turkey this ratio is 7.5$14 \%$ (Toksoy \& Bayramoğlu, 2016). In order to correct this situation, it is necessary to increase the weight of social and economic subjects such as public relations, management, business and law in forestry education in Turkey.

\section{ACKNOWLEDGEMENTS}

The authors wish to thank the many foresters working in the Turkish General Directorate of Forestry for contributing their time and valuable assistance, and specifically the teams responsible for preparing the Torul State Forest Enterprise forest management plans.

\section{REFERENCES}

Alphan, H. (2017). Analysis of landscape changes as an indicator for environmental monitoring. Environmental Monitoring and Assessment, 189, 1-24. doi:10.1007/s10661-016-5748-7

Alphan, H., \& Nil, Ç. (2016). Monitoring changes in landscape pattern: Use of Ikonos and Quickbird images. Environmental Monitoring and Assessment, 188, 81.doi: 10.1007/s10661-015-5089-y

Angelsen, A. (2007). Forest cover change in space and time: Combining the von Thunen and forest transition theories (Report No. 4117). Washington: World Bank Group.

Anonymous. (2015). Forestry Statistics 2015. Republic of Turkey Ministry of Forestry and Water Management. Retrieved

from https://www.ogm.gov.tr/ekutuphane/Istatistikler/Forms/AllItems.aspx?RootFolder=\%2Fekutuphane \% 2FIstatistikler\%2FOrmanc\%C4\%B11\%C4\%B1k\%20\%C4\%B0statistikleri\&FolderCTID=0x012000301D182F8 CB9FC49963274E712A2DC00\&View $=\{C 19 A B 316-F 6 A 1-40 F 4-B E 44-7526 A E 967 F D C\}$

Anonymous. (2016a). Per Person Gross National Product. Retrieved from https://biruni.tuik.gov.tr/ bolgeselistatistik/tabloYilSutunGetir.do?durum=yillariGetir\&menuNo=517\&altMenuGoster $=0 \& t a b l o N o=$ 336

Anonymous. (2016b). Republic of Turkey, State Institute of Statistics. Retrieved from http://rapor.tuik.gov.tr/reports/rwservlet?nufus80db2=\&ENVID=nufus80db2Env\&report=nfs80_ilce_ko y_sehir.RDF\&p_kod=1\&p_il=29\&p_kod=1\&p_yil=1965\&desformat=html

Başkent, E. Z., \& Kadıoğulları, A.İ. (2007). Spatial and temporal dynamics of land use pattern in Turkey: A case study in İnegöl. Landscape Urban Plan, 81, 316-327. doi:10.1016/j.landurbplan.2007.01.007

Beilin, R., Lindborg, R., Stenseke, M., Pereira, H. M., Llausàs, A., Slätmo, E., \& Queiroz C. (2014). Analysing how drivers of agricultural land abandonment affect biodiversity and cultural landscapes using case studies from Scandinavia, Iberia and Oceania. Land Use Policy, 36, 60-72. doi:10.1016/j.landusepol.2013.07.003

Bewket, W. (2002). Land cover dynamics since the 1950s in Chemoga watershed, Blue Nile Basin, Ethiopia. Mountain Research and Development, 22, 263-269. doi:10.1659/0276-4741(2002)022[0263:LCDSTI]2.0.CO;2

Call, M., Mayer, T., Sellers, S., Ebanks, D., Bertalan, M., Nebie, E., \& Gray C. (2017). Socio-environmental drivers of forest change in rural Uganda. Land Use Policy, 62, 49-58. doi:10.1016/j.landusepol.2016.12.012

Calvas, B., Knoke, T., Castro, L. M., Hildebrandt, P., Weber, M., Stimm, B., \& Aguirre, N. (2013). Sustainable agriculture and conservation payments are key factors in mitigating tropical forest loss. In: Bendix, J., E. Beck, A. Bräuning, F. Makeschin, R. Mosandl, S. Scheu, W. Wilcke (Eds.), Ecosystem services, biodiversity and environmental change in a tropical mountain ecosystem of South Ecuador (pp. 235-244). Berlin: Springer. 
Dewan, A. M., Yamaguchi, Y., \& Ziaur Rahman, M. (2012). Dynamics of land use/cover changes and the analysis of landscape fragmentation in Dhaka Metropolitan, Bangladesh. GeoJournal, 77, 315-330. doi:10.1007/s10708-010-9399-x

GDF (General Directorate of Forestry of Turkey). (2005). Forest Management Plans of Torul State Forest Enterprise. Ankara: GDF.

GDF (General Directorate of Forestry of Turkey). (2015). State of Turkey's Forest. Ankara: GDF.

GDF (General Directorate of Forestry of Turkey). (2016). Forest Management Plans of Torul State Forest Enterprise. Ankara: GDF.

Günlü, A., Kadıŏulları, A. İ., Keleş, S., \& Başkent, E. Z. (2009). Spatiotemporal changes of landscape pattern in response to deforestation in northeastern Turkey: A case study in Rize. Environmental Monitoring and Assessment, 148, 127-137. doi:10.1007/s10661-007-0144-y

Kadıoğulları, A. İ. (2013). Assessing implications of land use and land cover changes in forest ecosystems of NE Turkey. Environmental Monitoring and Assessment, 185, 2095-2106. doi:10.1007/s10661-012-2691-0

Kadıŏgulları, A. İ., \& Başkent, E. Z. (2008). Spatial and temporal dynamics of land use pattern in Turkey: A case study in Gümüşhane. Environmental Monitoring and Assessment, 138, 289-303. doi:10.1007/s10661-007-97988

Kadıŏulları, A. İ., Keleş, S., Başkent, E. Z., \& Günlü, A. (2008). Spatiotemporal Changes in Landscape Pattern in Response to Afforestation in Northeastern Turkey: A Case Study of Torul. Scottish Geographical Journal, 4, 259-273. doi:10.1080/14702540802566254

Kadıoğulları, A. İ., Sayin, M., Çelik, D., Borucu, S., Çil, B., \& Bulut, S. (2014). Analysing land cover changes for understanding of forest dynamics using temporal forest management plans. Environmental Monitoring and Assessment, 186, 2089-2110. doi:10.1007/s10661-013-3520-9

Lambin, E. F., \& Meyfroidt, P. (2010). Land use transition: socioecological feedback versus socio-economic change. Land Use Policy, 27, 108-118. doi:10.1016/j.landusepol.2009.09.003

Laurance W. F., Sayer, J., Cassman, K. G. (2014). Agricultural expansion and its impact on tropical nature. Trends in Ecology and Evolution, 29, 107-116. doi:10.1016/j.tree.2013.12.001

Lopez-Carr, D., \& Burgdorfer, J., (2013). Deforestation drivers: Population, migration and tropical land use. Evrironment Science and Policy for Sustainable Development, 55, 3-11. doi:10.1080/00139157.2013.748385

Meneses, B. M., Reis, E., Pereira, S., Vale, M. J., \& Reis, R. (2017). Understanding Driving Forces and Implications Associated with the Land Use and Land Cover Changes in Portugal. Sustainability, 9, 1-20. doi:10.3390/su9030351

Newman, M. E., McLaren, K. P., \& Wilson, B. S. (2014). Long-term socio-economicand spatial pattern drivers of land cover change in Caribbean tropical moist forest, the Cockpit Country, Jamaica. Agriculturei Ecosystems and Environment, 186, 185-200. doi:10.1016/j.agee.2014.01.030

Özen Turan, S., Kadığulları, A. İ., \& Günlü, A. (2010). Spatial and temporal dynamics of land use pattern response to urbanization in Kastamonu. African Journal of Biotechnology, 9, 640-647. Retrieved from http://www.ajol.info/index.php/ajb/article/view/78048

Padilla, F. M., Vidal, B., Sanchez, J., \& Pugnaire, F. I. (2010). Land-use changes and carbon sequestration through the twentieth century in a Mediterranean mountain ecosystem: Implications for land management. Journal of Environmental Management, 91, 2688-2695. doi:10.1016/j.jenvman.2010.07.031

Paudel, S., \& Yuan, R. (2012). Assessing landscape changes and dynamics using patch analysis and GIS modeling. International Journal of Applied Earth Observation and Geoinformation, 16, 66-76. doi:10.1016/j.jag.2011.12.003

Puyravaud, J. P. (2003). Standardizing the calculation of the annual rate of deforestation. Forest Ecology and Management, 177, 593-596. doi:10.1016/S0378-1127(02)00335-3

Sancar, C., Turan, S. Ö., \& Kadioğullari, A. İ. (2009). Land use-cover change processes in Urban fringe areas: Trabzon case study, Turkey. Scientific Research and Essay, 4, 1454-1462.

Sears R. R., Padoch, C., \& Pinedo-Vasquez, M. (2007). Amazon forestry transformed: Integrating knowledge for smallholder timber management in Eastren Brazil. Hum. Ecol., 35, 697-707. doi:10.1007/s10745-006-9109-y

Şen, G., Bayramoglu, M. M., \& Toksoy, D. (2015). Spatiotemporal changes of land use patterns in high mountain areas of Northeast Turkey: A case study in Maçka. Environ. Monit. Assess., 187, 515. doi:10.1007/s10661-015$4727-8$

Sloan, S. (2007). Fewer people may not mean more forest for Latin American forest frontiers. Biotropica, 39, 443-446. doi:10.1111/j.1744-7429.2007.00288.x 
Terzioğlu, S., Başkent, E. Z., \& Kadıoğulları, A. İ. (2009). Monitoring Structural Plant Diversity at Landscape Level: A Case Study of Scots Pine Forest in NE Turkey. Environmental Monitoring and Assessment, 152, 71-81. doi:10.1007/s10661-008-0297-3

Terzioğlu, S., Başkent, E.Z., Sivrikaya, F., Çakır, G., Kadığulları, A. İ., Başkaya, Ş., \& Keleş, S. (2010). Monitoring forest plant biodiversity changes and developing conservation strategies: A study from Camili Biosphere Reserve Area in NE Turkey. Biologia, 65, 843-852. doi:10.2478/s11756-010-0091-x

Toksoy, D., \& Bayramoğlu, M. M. (2016). Forestry Education and The Law No. 5531: A Sample of Karadeniz Technical University Forest Faculty Department of Forest Engineer, Ten Years of The Law No. 5531 (pp. 5981). Ankara: The Chamber of Forest Engineers.

Tritsch, I., \& Le Tourneau, F. M., (2016). Population densities and deforestation in the Brazilian Amazon: New insights on the current human settlement patterns. Applied Geography, 76, 163-172. doi:10.1016/j.apgeog.2016.09.022

Weinhold, D., Reis, E. J., \& Vale, P. M. (2015). Boom-bust patterns in the Brazilian Amazon. Glob. Environ. Change, 35, 391-399. doi:10.1016/j.gloenvcha.2015.09.013

Wyman, M. S., \& Stein, T. V. (2010). Modeling social and land-use/land cover change data to assess drivers of smallholder deforestation in Belize. Appl. Geogr., 30, 329-342. doi:10.1016/j.apgeog.2009.10.001

\section{http://www.ejmste.com}

